CONFRONTING INEQUALITY 



\title{
CONFRONTING INEQUALITY
}

\section{HOW SOCIETIES CAN CHOOSE INCLUSIVE GROWTH}

\author{
Jonathan D. Ostry, \\ Prakash Loungani, \\ and Andrew Berg
}

Foreword by Joseph E. Stiglitz 


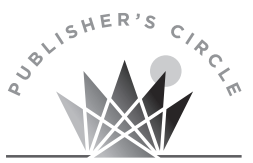

COLUMBIA

UNIVERSITY

PRESS

Columbia University Press gratefully acknowledges the generous contribution for this book provided by Publisher's Circle member Michael R. Yogg.

The views expressed in this book are those of the authors and do not necessarily represent the views of the IMF, its Executive Board, or IMF management.

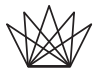 \\ Columbia University Press \\ Publishers Since 1893 \\ New York Chichester, West Sussex \\ cup.columbia.edu \\ Copyright (C) 2019 Columbia University Press \\ All rights reserved
}

Library of Congress Cataloging-in-Publication Data

Names: Ostry, Jonathan David, I962- author. | Loungani, Prakash, author. |

Berg, Andrew, author.

Title: Confronting inequality : how societies can choose inclusive growth /

Jonathan D. Ostry, Prakash Loungani, and Andrew Berg.

Description: New York : Columbia University Press, [2019] | Includes

bibliographical references and index.

Identifiers: LCCN 2018035788 | ISBN 9780231174688 (hardback) |

ISBN 9780231174695 (pbk.) | ISBN 97802315276 I3 (e-book)

Subjects: LCSH: Income distribution. | Equality-Economic aspects. |

Economic development.

Classification: LCC HC $79 . \mathrm{I}_{5} \mathrm{O}_{5} 2019$ | DDC 339.2-dc23 LC record available at https://lccn.loc.gov/2018035788

Columbia University Press books are printed on permanent and durable acid-free paper.

Printed in the United States of America

Cover design: Lisa Hamm 
To our wives: Rachel, Gail, and Katie

$\infty$

And our children:

Daniel and Joshua, David and Jonathan, and Sarah and Noah, in the hope that their world will be more inclusive than ours 
